\title{
Purification and Properties of the Endo-1,4- $\beta$-glucanase from Bacillus subtilis
}

\author{
By KIT-SING AU† AND K WONG-YU CHAN* \\ Department of Biology. The Chinese University of Hong Kong, Shatin, NT, Hong Kong
}

(Received 7 October 1986; rerised 17 Fehruary 1987)

Carboxymethylcellulase (endo-1,4- $\beta$-glucanase; EC 3.2.1.4) was purified from the culture filtrate of Bacillus subtilis $\mathrm{AU}-1$ by $\left(\mathrm{NH}_{4}\right)_{2} \mathrm{SO}_{4}$ precipitation. Avicel affinity chromatography, DEAE Sephadex G-75 chromatography and Sulphopropyl Sephadex C-50 chromatography. The enzyme was purified 36-fold and had an $M_{\mathrm{r}}$ of 23000 as determined by gel filtration on a Sephadex G-75 column. The pH optimum of the purified enzyme was $5 \cdot 5$; the enzyme was stable at $65^{\circ} \mathrm{C}$. Activity of the purified enzyme was significantly reduced by $\mathrm{Cu}^{2+}, \mathrm{Pb}^{2+}, \mathrm{Sn}^{2+}, \mathrm{Ag}^{+}$, $\mathrm{Hg}^{2+}$ and $\mathrm{Fe}^{2+}$, but was increased by $139.5 \%$ in the presence of $\mathrm{Co}^{2+}$. Inhibition studies indicated that the purified enzyme was either a metalloprotein or required certain metal ions for activation/stabilization; that iron was not a prosthetic group of the enzyme; that a tryptophanyl group was not involved in enzyme action; and that reduced thiol groups were required for enzyme activity and involved in the active site of the enzyme. The $K_{\mathrm{m}}$ of the purified enzyme for carboxymethylcellulose was $4 \mathrm{mg} \mathrm{ml}^{-1}$, and the $V_{\max }$ for carboxymethylcellulose hydrolysis was $0.42 \mathrm{mg} \mathrm{D}$-glucose $\mathrm{min}^{-1}(\mathrm{mg} \text { protein })^{-1}$.

\section{INTRODUCTION}

Cellulase has been used for industrial saccharification of cellulosic materials (Linko, 1977; Ryu \& Mandels, 1980). Although many cellulolytic micro-organisms have been studied as potential sources of cellulase. attention has focused on the fungus Trichoderma reesei (Mandels, 1982), the thermophilic cellulolytic species of Clostridium (Lee \& Blackburn, 1975; $\mathrm{Ng}$ et al., 1977: Shinmyo et al., 1979) and Thermomonospora (Moreira et al., 1981), and the mesophilic species of Cellulomonas (Langsford et al., 1984), Cytophaga (Chang \& Thayer, 1977) and Acetivibrio (Saddler \& Khan, 1980). Most of the information on the mechanism of cellulase activity has come from studies on purified cellulase from these micro-organisms (Beguin \& Eisen, 1978; Shoemaker \& Brown, 1978; Halliwell, 1979; Ng \& Zeikus, 1981; MacKenzie \& Bilous, 1982).

Many species of the bacterial genus Bacillus produce extracellular enzymes of industrial importance (Priest, 1977), including cellulase (K nösel, 1971; Fogarty \& Griffin, 1973; Zemek et al., 1981): there is, however, little information about the properties of the purified cellulases produced by these species. The purpose of the present study was to purify and characterize a major endo-1,4- $\beta$-glucanase (carboxymethylcellulase) of Bacillus subtilis AU-1.

\section{METHODS}

Organism and culture conditions. Bacillus subtilis AU-1 is a mutant obtained by treating $B$. subtilis T-14 with the mutagen $N$-methyl- $N^{\prime}$-nitro- $N$-nitrosoguanidine. The parent strain, $B$. subtilis $\mathrm{T}-14$, was originally isolated from cotton waste compost, and produces carboxymethylcellulase (CMCase) when grown in a liquid mineral medium containing yeast extract and $\mathrm{D}(+)$-raffinose as the major carbon source ( $\mathrm{Au} \&$ Chan, 1986).

† Present address: Department of Virology. Baylor College of Medicine, Houston, Texas 77030, USA.

Abbreviations: CMCase, carboxymethylcellulase: DNS, dinitrosalicylic acid. 
B. subtilis $\mathrm{AU}-\mathrm{I}$ was grown at $50^{\circ} \mathrm{C}$ in a liquid medium with the following composition: $\mathrm{D}(+)$-raffinose, $2 \mathrm{~g}$; $\mathrm{NH}_{4} \mathrm{Cl}, 1 \mathrm{~g} ; \mathrm{NaCl}, 0.6 \mathrm{~g} ; \mathrm{MgSO}_{4} .7 \mathrm{H}_{2} \mathrm{O}, 0.8 \mathrm{~g} ; \mathrm{K}_{2} \mathrm{HPO}_{4}, 5 \mathrm{~g} ; \mathrm{KH}_{2} \mathrm{PO}_{4}, 10 \mathrm{~g} ; \mathrm{CaCl}_{2} .2 \mathrm{H}_{2} \mathrm{O}, 0.15 \mathrm{mg} ;$ $\mathrm{MnSO}_{4} .4 \mathrm{H}_{2} \mathrm{O}, 0.5 \mathrm{mg} ; \mathrm{CoCl}_{2} .6 \mathrm{H}_{2} \mathrm{O}, 2 \mathrm{mg} ; \mathrm{FeSO}_{4} .7 \mathrm{H}_{2} \mathrm{O}, 0.1 \mathrm{mg} ; \mathrm{CuSO}_{4} .5 \mathrm{H}_{2} \mathrm{O}, 0.2 \mathrm{mg} ; \mathrm{ZnSO}{ }_{4} .7 \mathrm{H}_{2} \mathrm{O}, 0.5 \mathrm{mg}$; yeast extract, $5 \mathrm{~g}$; Casamino acids, $5 \mathrm{~g}$; proteose peptone, $5 \mathrm{~g}$; and $1000 \mathrm{ml}$ distilled water $(\mathrm{pH} \mathrm{6.0)}$ ).

Enzyme assays. CMCase (EC 3.2.1.4) was assayed according to Stewart \& Leatherwood (1976). The reaction mixture contained $1 \mathrm{ml} \mathrm{l} \%(\mathrm{w} / \mathrm{v})$ carboxymethylcellulose (Sigma) in $0.05 \mathrm{M}$-potassium phosphate buffer ( $\mathrm{pH} \mathrm{6.0)}$ and $1 \mathrm{ml}$ of clarified culture supernatant. The mixture was incubated at $50{ }^{\circ} \mathrm{C}$ for $30 \mathrm{~min}$, and the reaction was stopped by the addition of $2 \mathrm{ml}$ 3,5-dinitrosalicylic (DNS) acid reagent (Miller, 1959). The tubes were covered and placed in boiling water for $10 \mathrm{~min}$, and the absorbance values at $575 \mathrm{~nm}$ were then read against blanks containing equivalent amounts of boiled enzyme. Glucose equivalents were obtained by reference to a standard curve. One unit $(U)$ of $C M C a s e$ activity was defined as the amount of enzyme required to liberate $1 \mu \mathrm{g}$ reducing sugar as D-glucose in $30 \mathrm{~min}$.

Avicelase (EC 3.2.1.74) was also assayed by the DNS method. The reaction mixture was the same as that for the CMCase assay except that the substrate used was $1 \mathrm{ml}$ of $1 \%$ (w/v) Sigmacell type 20 (Sigma). One unit (U) of enzyme activity was defined as the amount of enzyme which released $1 \mu \mathrm{g}$ reducing sugar in $30 \mathrm{~min}$.

Protein determination. Protein was determined by the Lowry method with bovine serum albumin as a standard.

Enzyme purification. B. subtilis AU-1 was grown at $50^{\circ} \mathrm{C}$ in the above culture medium with shaking for $20 \mathrm{~h}$. The culture was centrifuged at $10000 \mathrm{~g}$ for $15 \mathrm{~min}$ at $4^{\circ} \mathrm{C}$, and the supernatant containing CMCase activity was collected. Solid $\left(\mathrm{NH}_{4}\right)_{2} \mathrm{SO}_{4}$ was slowly added to the supernatant and finally the protein precipitate was collected by centrifugation at $9000 \mathrm{~g}$ for $30 \mathrm{~min}$. The proteins were resuspended in the minimum volume of $20 \mathrm{~mm}$ ammonium acetate buffer ( $\mathrm{pH} 5 \cdot 0$ ). The enzyme solution was then dialysed against the same buffer for $24 \mathrm{~h}$ at $5{ }^{\circ} \mathrm{C}$.

An Avicel affinity column $(18 \times 800 \mathrm{~mm})$ was prepared according to Gum \& Brown (1976); it contained Sigmacell type 20 (Sigma) equilibrated in $50 \mathrm{~mm}$-citric acid/100 mM- $\mathrm{Na}_{2} \mathrm{HPO}_{4}$ buffer (pH $5 \cdot 0$ ). Lyophilized fractions from the $\left(\mathrm{NH}_{4}\right)_{2} \mathrm{SO}_{4}$ precipitation $(30 \%$ saturation) in the same buffer were applied to the column and eluted at $5{ }^{\circ} \mathrm{C}$ with the same buffer at a flow rate of $8 \mathrm{ml} \mathrm{h}^{-1}$. The eluted fractions containing CMCase activity were pooled and dialysed against distilled water for $12 \mathrm{~h}$. The dialysed enzyme solution was then applied to a column $(1.0 \times 50 \mathrm{~cm})$ of DEAE Sephadex G-75 at $5{ }^{\circ} \mathrm{C}$. The gel was equilibrated with $50 \mathrm{~mm}$-citric acid/100 mM$\mathrm{Na}_{2} \mathrm{HPO}_{4}$ buffer (pH 5.0 ) containing $0.03 \%$ sodium azide. At a flow rate of $4 \mathrm{ml} \mathrm{h}^{-1}$, fractions $(1.5 \mathrm{ml}$ ) were collected, and those fractions with high CMCase activity were combined and dialysed against distilled water for $20 \mathrm{~h}$. This concentrated enzyme solution was applied to a Sulphopropyl Sephadex C-50 column $(2.5 \times 30 \mathrm{~cm})$ that was eluted with a continuous gradient of $\mathrm{NaCl}(0$ to $0.4 \mathrm{M})$ in $50 \mathrm{mM}$-sodium citrate buffer (pH 3.5) at $5{ }^{\circ} \mathrm{C}$. A constant flow rate of $14 \mathrm{ml} \mathrm{h}^{-1}$ was used, and $2 \mathrm{ml}$ fractions were collected. After dialysis against distilled water for $20 \mathrm{~h}$, the enzyme fraction was subjected to purity determination by PAGE.

E!ectrophoresis under nondenaturing conditions was done in a $7.5 \%(\mathrm{w} / \mathrm{v})$ polyacrylamide slab gel with $1.5 \mathrm{M}$ Tris/ $\mathrm{HCl}$ buffer $(\mathrm{pH} 6.8)$. The enzyme $(20 \mu \mathrm{g})$ was subjected to electrophoresis in the presence of $0.1 \% \mathrm{SDS}$ at a current of $30 \mathrm{~mA}$. The gels were stained for protein with Coomassie brilliant blue R-250 and destained in methanol/acetic acid/water $(5: 2: 5$, by vol.).

Determination of $M_{r}$. The $M_{\mathrm{r}}$ of the CMCase was estimated by gel filtration on a Sephadex G-75 column $(1.0 \times$ $50 \mathrm{~cm}$ ) according to the method of Andrews (1964). The $M_{\mathrm{r}}$ standards used were haemoglobin (BDH; $M_{\mathrm{r}} 64500$ ), $\alpha$-amylase (Sigma; $M_{\mathrm{r}}$ 48500), subtilisin (Sigma; $M_{\mathrm{r}} 26700$ ), and lysozyme (Merck; $M_{\mathrm{r}} 14300$ ).

Chromatography of hydrolysis products. The purified CMCase was incubated with Whatman no. 1 filter paper $\left(20 \mathrm{mg} \mathrm{ml}^{-1}\right)$, Sigmacell type $20\left(20 \mathrm{mg} \mathrm{ml}^{-1}\right)$, or $0.2 \%$ carboxymethylcellulose at $50^{\circ} \mathrm{C}$ for $30 \mathrm{~min}$. Then $0.1 \mathrm{ml}$ of the enzyme digest was added to $1 \mathrm{ml}$ ice-cold ethanol/acetone $(1: 2, \mathrm{v} / \mathrm{v})$ to precipitate protein. The supernatant was obtained by centrifugation at $10000 \mathrm{~g}$ for $10 \mathrm{~min}$, and residual ethanol and acetone were removed under vacuum. Then the hydrolysis products were analysed by ascending chromatography of $10 \mu \mathrm{l}$ samples on precoated Silica Gel 60 plates (Merck), using an ethyl acetate/methanol/acetic acid/water $(12: 3: 3: 2$, by vol.) solvent system. Reference sugars used were $\mathrm{D}$-glucose, $\mathrm{D}(+)$-cellobiose and $\mathrm{D}$-fructose. The chromatogram was developed with 4-aminobenzoic acid reagent ( $2 \mathrm{~g} 4$-aminobenzoic acid, $1.64 \mathrm{ml} \mathrm{88 \% ,w/v,} \mathrm{phosphoric} \mathrm{acid} \mathrm{and} 36 \mathrm{ml}$ acetic acid in $40 \mathrm{ml}$ distilled water).

Substrate specificity of the purified CMCase. This was determined according to a modification of the method of Shepherd et al. (1981). Each substrate (see Table 2) was preincubated with $0.9 \mathrm{ml} 0.05 \mathrm{M}$-citric acid/0.1 M$\mathrm{Na}_{2} \mathrm{HPO}_{4}$ buffer $\left(\mathrm{pH} \mathrm{6.0)}\right.$ at $50^{\circ} \mathrm{C}$ for $10 \mathrm{~min}$, and then $0.1 \mathrm{ml}$ of enzyme in the same buffer was added and incubation was continued for another $30 \mathrm{~min}$ before CMCase activity was assayed.

Effects of $\mathrm{pH}$ and temperature on the purified CMCase. The optimum $\mathrm{pH}$ for CMCase activity and the effect of temperature on activity were determined by adding $0.1 \mathrm{ml}$ purified enzyme solution to $0.25 \mathrm{ml}$ each of the following buffers : $0.1 \mathrm{M}$-citric acid/0.2 $\mathrm{M}-\mathrm{Na}_{2} \mathrm{HPO}_{4}(\mathrm{pH} 3.0$ to 8.0 ), and $0.2 \mathrm{M}$-glycine/0.2 $\mathrm{M}-\mathrm{NaOH}$ (pH 8.0 to 10). Then $0.25 \mathrm{ml}$ of $20 \mathrm{mg}$ carboxymethylcellulose $\mathrm{ml}^{-1}$ in deionized water was added; the mixture was incubated at between 20 and $80^{\circ} \mathrm{C}$ for $30 \mathrm{~min}$, and enzyme activity was assayed.

The $\mathrm{pH}$ stability of the enzyme was studied by preincubating $0.1 \mathrm{ml}$ enzyme solution with $0.1 \mathrm{ml}$ buffer $(0.1 \mathrm{M}-$ citric acid $/ 0.2 \mathrm{M}-\mathrm{Na}_{2} \mathrm{HPO}_{4}$ buffer for $\mathrm{pH} 3.0$ to 8.0 , and $0.2 \mathrm{M}$-glycine $/ 0.2 \mathrm{M}-\mathrm{NaOH}$ buffer for $\mathrm{pH} 8.0$ to 10 ) at $50^{\circ} \mathrm{C}$ 
for $10 \mathrm{~min}$. Then $0.8 \mathrm{ml}$ of $20 \mathrm{mg}$ carboxymethylcellulose $\mathrm{ml}^{-1}$ in $0.1 \mathrm{M}$-citric acid $/ 0.2 \mathrm{M}-\mathrm{Na}_{2} \mathrm{HPO}_{4}$ buffer (pH 6.0) was added in order to assay for residual CMCase activity at $50^{\circ} \mathrm{C}$.

Temperature stability of the purified CMCase was evaluated by incubating $0.1 \mathrm{ml}$ enzyme solution in $0.1 \mathrm{ml} 0.1$ M-citric acid/0.2 $\mathrm{M}-\mathrm{Na}_{2} \mathrm{HPO}_{4}$ buffer $(\mathrm{pH} \mathrm{6.0)}$ at various temperatures for $60 \mathrm{~min}$; the residual CMCase activity was then assayed.

Effects of cations and various reagents on enzyme activity. Individual cations (see Table 3 ) and reagents (see Table 4) in $0.1 \mathrm{M}$-citric acid/0.2 $\mathrm{M}-\mathrm{Na}_{2} \mathrm{HPO}_{4}$ buffer ( $\mathrm{pH} \mathrm{6.0)}$ were added to a reaction mixture containing purified CMCase and carboxymethylcellulose in the same buffer, and the CMCase activity was assayed.

\section{RESULTS}

Initial $\left(\mathrm{NH}_{4}\right)_{2} \mathrm{SO}_{4}$ fractionation showed that $92 \%$ of the enzyme activity was recovered between 10 and $40 \%\left(\mathrm{NH}_{4}\right)_{2} \mathrm{SO}_{4}$ saturation, and highest CMCase activity $(3724.8 \mathrm{U})$ was associated with the 30 to $40 \%$ saturated $\left(\mathrm{NH}_{4}\right)_{2} \mathrm{SO}_{4}$ pellet; therefore only pellets from the latter range were used for chromatography on the Avicel affinity column. The affinity chromatography produced one major protein peak which contained $70.6 \%$ of the CMCase activity (Fig. 1). Two peaks of Avicelase activity were also observed; however the activities of these two peaks were relatively low (Fig. 1).

The pooled fractions containing the CMCase activity from the Avicel affinity column were applied to the DEAE Sephadex G-75 column; this yielded one major peak (peak C) and two minor peaks (peaks A and B) of CMCase activity (Fig. 2). The major peak contained $87 \%$, and the two minor peaks respectively $10 \%$ and $7 \%$ of the total CMCase activity applied to the column. Only fractions comprising peak $\mathrm{C}$ were pooled and further purified by Sulphopropyl Sephadex C-50 chromatography. Two protein components were obtained by elution with a linear gradient of $\mathrm{NaCl}$, and the major $\mathrm{CMCase}$ activity coincided with the smaller protein peak (Fig. 3). The CMCase activity contained in the other protein peak was too low for further purification. Fractions of the major CMCase peak were pooled and subjected to PAGE, which revealed a single band of protein. A 36-fold purification of CMCase was achieved in triplicate experiments (Table 1).

Kinetic study of the purified CMCase showed that the $K_{\mathrm{m}}$ for carboxymethylcellulose was $4 \mathrm{mg} \mathrm{ml}^{-1}$, and the $V_{\max }$ for carboxymethylcellulose hydrolysis was $0.42 \mathrm{mg} \mathrm{D}^{2}$ glucose $\mathrm{min}^{-1}$ (mg protein $)^{-1}$ as determined from the Lineweaver-Burk plot.

The $M_{\mathrm{r}}$ of the purified enzyme was estimated to be 23000 .

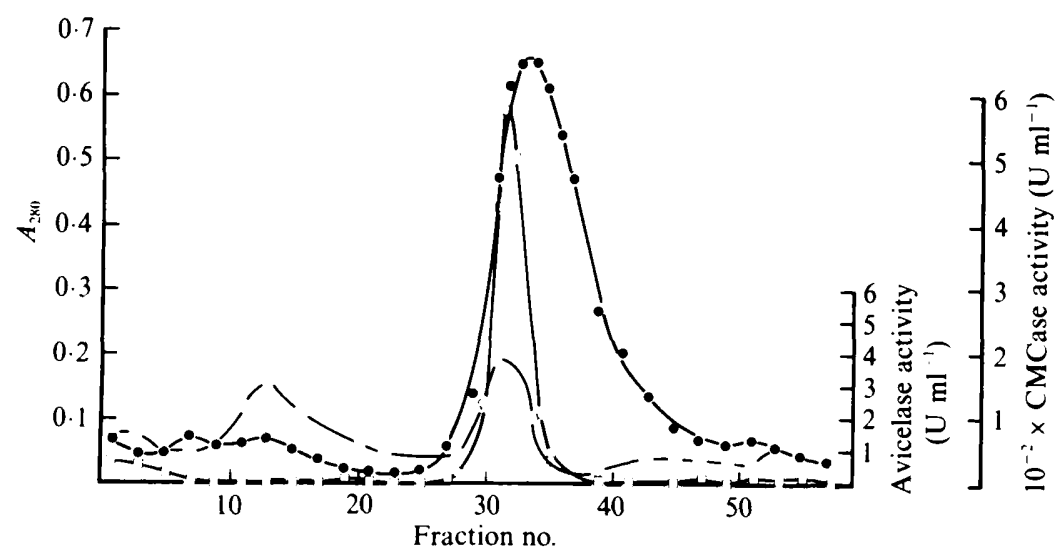

Fig. 1. Elution profile of CMCase and Avicelase on an Avicel affinity chromatography column. The column $(18 \times 800 \mathrm{~mm})$ was equilibrated with $50 \mathrm{~mm}$-citric acid/100 mM-Na $\mathrm{HPO}_{4}$ buffer $(\mathrm{pH} 5 \cdot 0)$. Lyophilized fractions from the $\left(\mathrm{NH}_{4}\right)_{2} \mathrm{SO}_{4}$ precipitation in the same buffer were applied to the column, which was then eluted with the equilibration buffer at a flow rate of $4 \mathrm{ml} \mathrm{h}^{-1}$. Fractions (1.5 ml) were collected and assayed: $O$, protein: $\square$, CMCase activity; $O$, Avicelase activity. 


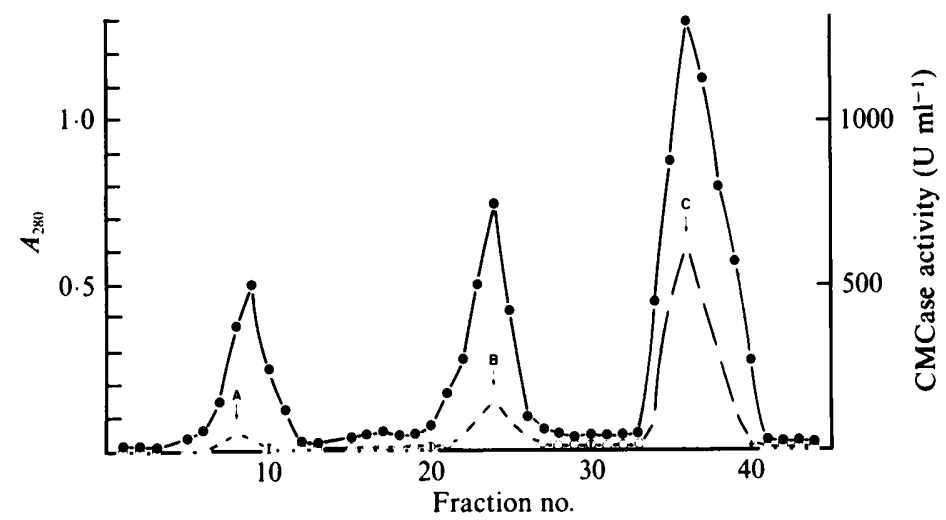

Fig. 2. Separation of the CMCase activities on a DEAE Sephadex G-75 column. Dialysed fractions containing CMCase activity obtained after A vicel affinity chromatography were applied to the column $(1.0 \times 50 \mathrm{~cm})$ which was equilibrated with $50 \mathrm{~mm}$-citric acid/100 mM-Na ${ }_{2} \mathrm{HPO}_{4}$ buffer $(\mathrm{pH} 5.0)$ containing $0.03 \%$ sodium azide. Fractions $(1.5 \mathrm{ml})$ were collected and assayed: $\mathrm{O}, \mathrm{CMCase}$ activity; -, protein.

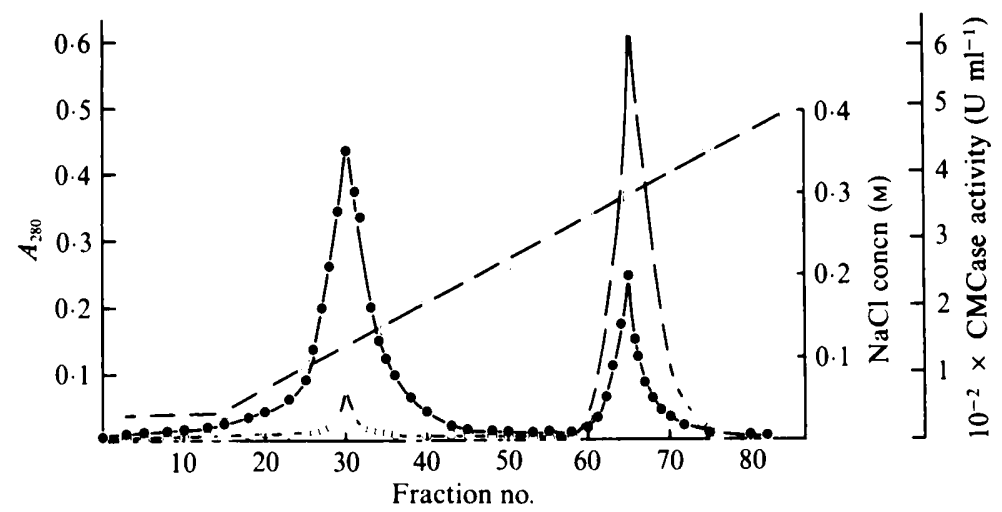

Fig. 3. Separation of CMCase peak C components on a Sulphopropyl Sephadex C-50 column. The column $(2.5 \times 30 \mathrm{~cm})$ was equilibrated with $50 \mathrm{mM}$-sodium citrate buffer $(\mathrm{pH} 3.5)$. The dialysed fractions of CMCase peak C obtained after DEAE Sephadex G-75 column chromatography were applied to the column, which was eluted with a continuous gradient of 0 to $0.4 \mathrm{M}-\mathrm{NaCl}$ ( $\square$ ) in $50 \mathrm{mM}$ sodium citrate buffer ( $\mathrm{pH} \mathrm{3.5)}$. Fractions ( $2 \mathrm{ml})$ were collected and assayed: $\mathrm{O}, \mathrm{CMCase}$ activity; protein.

Table 1. Purification of the CMCase from B. subtilis $A U-1$

\section{Procedure}

Cell-free supernatant

$\left(\mathrm{NH}_{4}\right)_{2} \mathrm{SO}_{4}$ precipitation

Affinity chromatography

DEAE Sephadex G-75

chromatogaphy

Sulphopropyl Sephadex C-50 chromatography
Total protein Total activity

(U)
Purification
(-fold)

$\left[\mathrm{U}(\mathrm{mg} \text { protein })^{-1}\right] \quad(\%) \quad(-$ fold $)$

$\begin{array}{clccc}100 & 4174 \cdot 35 & 41 \cdot 75 & 100 & - \\ 62 & 3724 \cdot 8 & 60 & 89 & 1.4 \\ 29.5 & 2947 & 100 & 71 & 2.4 \\ 2.7 & 2223.5 & 823 \cdot 5 & 53 & 19 \cdot 7 \\ & & & & \\ 1.1 & 1654.5 & 1504 & 39.6 & 36\end{array}$


Table 2. Substrate specificity of CMCase

Each substrate was preincubated with $0.9 \mathrm{ml} 0.05 \mathrm{M}$-citric acid $/ 0 \cdot 1 \mathrm{M}-\mathrm{Na}_{2} \mathrm{HPO}_{4}$ buffer $\left(\mathrm{pH} 6.0\right.$ ) at $50{ }^{\circ} \mathrm{C}$ for $10 \mathrm{~min}$ before addition of $0.1 \mathrm{ml}$ enzyme in the same buffer. The mixture was further incubated for $30 \mathrm{~min}$ before CMCase activity was assayed.

Substrate Concn $\left(\mathrm{mg} \mathrm{ml}^{-1}\right) \quad$ CMCase activity $\left(\mathrm{U} \mathrm{ml}^{-1}\right)$

$\begin{array}{lrc}\text { Carboxymethylcellulose } & 6 & 79 \cdot 5 \\ \text { Sigmacell type } 20 & 20 & 0 \cdot 74 \\ \alpha \text {-Cellulose } & 20 & 1 \cdot 56 \\ \text { Cellulose-azure } & 20 & 8 \cdot 1\end{array}$

Table 3. Effect of cations on CMCase activity

Each compound, dissolved in $0.1 \mathrm{M}$-citric acid/0.2 $\mathrm{M}-\mathrm{Na}_{2} \mathrm{HPO}_{4}$ buffer ( $\mathrm{pH} 6.0$ ), was added to the standard assay system and assayed at $50{ }^{\circ} \mathrm{C}$. $100 \%$ activity is equivalent to $184 \mathrm{U} \mathrm{ml}^{-1}$.

\begin{tabular}{lcclcc}
\multicolumn{1}{c}{ Cation } & Concn $(\mathrm{mm})$ & Relative activity $(\%)$ & \multicolumn{1}{c}{ Cation } & Concn (mM) & Relative activity $(\%)$ \\
Control & & 100 & $\mathrm{Ca}^{2+}\left(\mathrm{CaCl}_{2}\right)$ & 10 & 132 \\
$\mathrm{NH}_{4}^{+}\left(\mathrm{NH}_{4} \mathrm{Cl}\right)$ & 200 & $12 \cdot 96$ & $\mathrm{Cu}^{2+}\left(\mathrm{CuSO}_{4}\right)$ & 1 & $23 \cdot 8$ \\
$\mathrm{Ag}^{+}\left(\mathrm{AgNO}_{3}\right)$ & $0 \cdot 1$ & $48 \cdot 91$ & $\mathrm{~Pb}^{2+}\left(\mathrm{PbCl}_{2}\right)$ & 1 & 48 \\
$\mathrm{Na}^{+}(\mathrm{NaCl})$ & 100 & $137 \cdot 33$ & $\mathrm{Zn}^{2+}\left(\mathrm{ZnSO}_{4}\right)$ & 1 & 75 \\
$\mathrm{~K}^{+}(\mathrm{KCl})$ & 100 & 140 & $\mathrm{Mg}^{2+}\left(\mathrm{MgSO}_{4}\right)$ & 10 & 143 \\
$\mathrm{Hg}^{2+}\left(\mathrm{HgCl}_{2}\right)$ & $0 \cdot 1$ & $51 \cdot 6$ & $\mathrm{Mn}^{2+}\left(\mathrm{MnCl}_{2}\right)$ & 1 & 164 \\
$\mathrm{Fe}^{2+}\left(\mathrm{FeSO}_{4}\right)$ & 1 & 50 & $\mathrm{Co}^{2+}\left(\mathrm{CoCl}_{2}\right)$ & 1 & $239 \cdot 5$ \\
$\mathrm{Sn}^{2+}\left(\mathrm{SnCl}_{2}\right)$ & $0 \cdot 1$ & $56 \cdot 5$ & & &
\end{tabular}

Substrate specificity and hydrolysis products of the purified CMCase. The purified enzyme displayed highest activity towards carboxymethylcellulose and significantly lower activity toward $\alpha$-cellulose and cellulose-azure (Table 2). Notably, the enzyme was five times more active towards dyed cellulose than towards $\alpha$-cellulose. In addition, the enzyme showed negligible activity towards Avicel (Sigmacell type 20).

Hydrolysis of carboxymethylcellulose by the action of the purified CMCase resulted in the formation of glucose and cellobiose. No soluble sugars were detected as hydrolysis products from Whatman no. 1 filter paper and Sigmacell type 20.

Effects of temperature and $\mathrm{pH}$ on the activity and stability of purified CMCase. The CMCase was active up to $70^{\circ} \mathrm{C}$, and was stable for $60 \mathrm{~min}$ up to $65^{\circ} \mathrm{C}$; above this temperature activity fell rapidly.

The optimum $\mathrm{pH}$ for the purified enzyme was 5.5 ; at $50{ }^{\circ} \mathrm{C}$ the purified enzyme was stable at $\mathrm{pH} 5.0$ and over $95 \%$ of activity was retained at $\mathrm{pH} 5.5$ to 8.0 .

Effects of cations and various reagents on the activity of purified CMCase. Significant inactivation of the enzyme was observed with $\mathrm{Cu}^{2+}, \mathrm{Pb}^{2+}, \mathrm{Sn}^{2+}, \mathrm{Ag}^{+}, \mathrm{Hg}^{2+}$ and $\mathrm{Fe}^{2+}$ (Table 3). On the other hand, the addition of $\mathrm{Co}^{2+}$ increased the enzyme activity by $139.5 \%$ over that of the control (no added cations).

Among the various reagents tested (Table 4) the reducing agent dithiothreitol, and the amines, polyols and histamine, stimulated enzyme activity while all three thiol-group-binding agents and sodium sulphite inhibited CMCase activity. In addition, EDTA inhibited enzyme activity by $17 \%$ and sodium azide did not affect enzyme activity.

\section{DISCUSSION}

It is generally agreed that microbial cellulases are difficult to purify (Tong et al., $1980 ; \mathrm{Ng} \&$ Zeikus, 1981). Fractionation of the crude cellulolytic activity produced by $B$. subtilis AU-1 into as many different components as possible was not the objective of the present study. Rather, the purification scheme was designed for the isolation of one homogeneous endo-1,4- $\beta$-glucanase 
Table 4. Effect of various reagents on CMCase activity

Each reagent dissolved in $0 \cdot 1 \mathrm{M}$-citric acid/0.2 $\mathrm{M}-\mathrm{Na}_{2} \mathrm{HPO}_{4}$ buffer $(\mathrm{pH} 6 \cdot 0)$ was added to the standard assay system and assayed at $50{ }^{\circ} \mathrm{C}$. $100 \%$ activity is equivalent to $192 \mathrm{U} \mathrm{ml}^{-1}$.

\begin{tabular}{|c|c|c|}
\hline Reagent & Concn (mM) & Relative activity $(\%)$ \\
\hline Control & & 100 \\
\hline $\begin{array}{l}\text { Reducing agent } \\
\text { Dithiothreitol }\end{array}$ & 5 & 128.8 \\
\hline $\begin{array}{l}\text { Thiol-group binding agents } \\
\text { Mercuric chloride } \\
\text { Sodium arsenite }\end{array}$ & $\begin{array}{l}0 \cdot 1 \\
0 \cdot 1\end{array}$ & $\begin{array}{l}51.6 \\
58.5\end{array}$ \\
\hline $\begin{array}{l}\text { Disulphide bond cleaving agent } \\
\text { Sodium sulphite }\end{array}$ & $0 \cdot 1$ & 72 \\
\hline $\begin{array}{l}\text { Amines } \\
\text { Glycine } \\
\text { L-Histidine }\end{array}$ & $\begin{array}{l}50 \\
50\end{array}$ & $\begin{array}{l}170.9 \\
132.6\end{array}$ \\
\hline $\begin{array}{l}\text { Polyols } \\
\text { Arabitol } \\
\text { Erythritol } \\
\text { Glycerol }\end{array}$ & $\begin{array}{l}50 \\
50 \\
50\end{array}$ & $\begin{array}{l}151 \cdot 7 \\
157 \\
139\end{array}$ \\
\hline $\begin{array}{l}\text { Trypophanyl group binding agent } \\
\text { Histamine }\end{array}$ & 20 & 124 \\
\hline $\begin{array}{l}\text { Metallo-enzyme inhibitors } \\
\text { EDTA } \\
\text { Sodium azide }\end{array}$ & $\begin{array}{r}50 \\
5\end{array}$ & $\begin{array}{l}83 \cdot 4 \\
99 \cdot 3\end{array}$ \\
\hline
\end{tabular}

(CMCase) from the crude enzyme preparation. In order to avoid loss of activity, the purification processes did not include DEAE cellulose chromatography. Since highest CMCase activity was found to associate with the 30 to $40 \%$ saturated $\left(\mathrm{NH}_{4}\right)_{2} \mathrm{SO}_{4}$ pellet, only enzyme from this fraction was collected and used for further purification. A similar observation has been reported for the CMCase isolated from Thermoascus aurantiacus (Tong et al., 1980). The high percentage (70.6\%) of protein recovery from the Avicel affinity chromatography was probably due to the fact that the CMCase, as the major component of the enzyme preparation, has little affinity for Avicel (Sigmacell type 20). The observation of a single peak of high CMCase activity and two peaks of relatively low Avicelase activity supports the view that CMCase is the major component of the cellulase system in $B$. subtilis AU-1.

Chromatography on DEAE Sephadex G-75 revealed three peaks (A, B and C) of CMCase activity, and subsequent effort was spent to purify the CMCase from peak $\mathrm{C}$ which comprises $87 \%$ of the total CMCase activity applied to the column. Sulphopropyl Sephadex C-50 column chromatography further separated peak $\mathrm{C}$ activity into two protein components, of which the peak containing almost all the CMCase activity was confirmed to comprise a single protein species as evidenced by its appearance as a single protein band on PAGE.

The CMCase of $B$. subtilis AU-1 has a smaller $M_{\mathrm{r}}$ than other purified bacterial CMCases (Beguin \& Eisen, 1978; $\mathrm{Ng} \&$ Zeikus, 1981 ; Groleau \& Forsberg, 1983). The $K_{\mathrm{m}}\left(4 \mathrm{mg} \mathrm{ml}^{-1}\right)$ for carboxymethylcellulose of the purified CMCase is similar to that of Thermoascus aurantiacus (Tong et al., 1980), and higher than those of Trichoderma reesei (Shoemaker \& Brown, 1978) and Cytophaga spp. (Chang \& Thayer, 1977).

In general, cellulases have high temperature optima when compared with other enzyme systems. The purified CMCase of $B$. subtilis AU-1 remained totally active up to $70{ }^{\circ} \mathrm{C}$, which is higher than reported for Clostridium thermocellum ( $\mathrm{Ng} \&$ Zeikus, 1981), Aspergillus niger (Hurst et al., 1977) and Humicola lanuginosa (Olutiola, 1982), and is comparable to temperature optima of cellulases from the thermophiles Thermoascus aurantiacus (Tong et al., 1980) and Thermomonospora sp. (Hägerdal et al., 1980).

The hydrolysis of carboxymethylcellulose by the purified CMCase produced glucose and cellobiose. This differs from the report by Chang \& Thayer (1977) on Cytophaga cellulase, which 
produced only glucose from carboxymethylcellulose, and from Pseudomonas cellulase, which produced galactose, mannose, fucose and glucosamine (Yamane et al., 1970).

Our results suggest that reduced thiol groups are required for CMCase activity in B. subtilis AU-1, and that these groups are involved in the active site of the enzyme. Similar results have been reported for the cellulase of Acetivibrio cellulolyticus (MacKenzie \& Bilous, 1982) and Humicola lanuginosa (Olutiola, 1982). It is conceivable that the inhibition of CMCase activity by sodium sulphite is due to partial damage or alteration of the molecular configuration of the enzyme by cleavage of the disulphide linkages present in the enzyme molecule. It has been reported that inhibition of protein activity by compounds containing a protonated imidazole ring such as histamine was at least partially due to the formation of a charge-transfer complex with the tryptophanyl group of the proteins (Shinitzky et al., 1966). The fact that histamine did not inhibit CMCase activity might therefore imply that a tryptophanyl group is not involved in the enzyme action. In addition, our results on the effects of EDTA and sodium azide on the purified enzyme imply that (1) iron is not a prosthetic group of the enzyme, and (2) the enzyme is a metallo-protein or it requires certain metal ions for activation and/or for stabilization. The CMCase purified in the present study represents only a portion of the total endoglucanase activity of $B$. subtilis AU-1.

\section{REFERENCES}

ANDREw, P. (1964). Estimation of molecular weight of protein by Sephadex gel filtration. Biochemical Journal 91, 222-233.

AU, K. S. \& Chan, K.-Y. (1986). Carboxymethylcellulase production by Bacillus subtilis. Microbios $\mathbf{4 8}$, 93- 108.

Beguin, P. \& Eisen, H. (1978). Purification and partial characterization of three extracellular cellulases from Cellulomonas sp. European Journal of Biochemistry 87, 525-531.

Chang, W. T. H. \& Thayer, D. W. (1977). The cellulase system of Cytophaga species. Canadian Journal of Microbiology 23, 1285-1292.

Fogarty, W. M. \& Griffin, P. J. (1973). Some preliminary observations on the production and properties of a cellulolytic enzyme elaborated by Bacillus polymyxa. Biochemical Society Transactions 1, 44-45.

Groleau, D. \& Forsber, C. W. (1983). Partial characterization of the extracellular carboxymethylcellulase activity produced by the rumen bacterium Bacteroides succinogenes. Canadian Journal of Microbiology 29, 504-517.

GUM, E. K., JR \& BROWN, R. D., JR (1976). Structural characterization of a glycoprotein cellulase, $1,4-\beta$-Dglucan cellohydrolase $\mathrm{C}$ from Trichoderma viride. Biochimica et biophysica acta 446, 371-386.

Hägerdal, B. G. B., Ferchak, J. D. \& Pye, E. K. (1978). Saccharification of cellulose by the cellulolytic enzyme system of Thermomonospora sp. I. Stability of cellulolytic activities with respect to time, temperature, and $\mathrm{pH}$. Biotechnology and Bioengineering 22, 1516-1526.

Halliwell, G. (1979). Microbial $\beta$-glucanases. Progress in Industrial Microbiology 15, 1-60.

Hurst, P. L., Sullivan, P. A. \& Shepherd, M. G. (1977). Chemical modification of a cellulase from Aspergillus niger. Biochemical Journal 167, 549-556.

KNÖSEL, D. (1971). Continued investigation for pectolytic and cellulolytic activity of different Bacillus species. Zentralblatt für Bakteriologie 126, 604609.
Langsford, M. L., Gilkes, N. R., Wakarchuk, W. W., Kilburn, D. G., Miller, R. C., JR \& Warren, R. A. J. (1984). The cellulase system of Cellulomonas fimi. Journal of General Microbiology 130, 1367-1376.

LeE, R. H. \& Blackburn, T. H. (1975). Cellulase production by a thermophilic Clostridium species. Applied Microbiology 30, 346-353.

LiNKo, M. (1977). An evaluation of enzymatic hydrolysis of cellulosic materials. In Advances in Biochemical Engineering, vol. 5, pp. 25-48. Edited by T. K. Ghose, A. Fiechter \& N. Blakebrough. Berlin: Springer-Verlag.

MACKenzie, C. R. \& Bilous, D. (1982). Location and kinetic properties of the cellulase system of Acetivibrio cellulolyticus. Canadian Journal of Microbiology 28, $1158-1164$.

Mandels, M. (1982). Cellulases. In Annual Reports on Fermentation, vol. 5, pp. 35-78. Edited by G. T. Tsao. New York: Academic Press.

Miller, G. L. (1959). Use of dinitrosalicylic acid reagent for determination of reducing sugar. Analytical Chemistry 31, 426-428.

Moreira, A. R., Phillips, J. A. \& Humphrey, A. E. (1981). Production of cellulases by Thermomonospora sp. Biotechnology and Bioengineering 23, 1339-1347.

NG, T. K. \& Zeikus, J. G. (1981). Purification and characterization of an endoglucanase $(1,4-\beta$-D-glucan glucanohydrolase) from Clostridium thermocellum. Biochemical Journal 199, 341-350.

Ng, T. K., Weimer, P. J. \& Zeikus, J. G. (1977). Cellulolytic and physiological properties of Clostridium thermocellulum. Archives of Microbiology 114, $1-7$.

Olutiola, P. O. (1982). Characterization of cellulase from Humicola lanuginosa. Experientia 38, $1332-$ 1333.

PRIEST, F. G. (1977). Extracellular enzyme synthesis in the genus Bacillus. Bacteriological Reviews 42, 711 753.

RYU, D. D. \& Mandels, M. (1980). Cellulases: biosynthesis and application. Enzyme and Microbial Technology 2, 91-101. 
SAdDler, J. N. \& KhaN, A. W. (1980). Cellulase production by Acetivibrio cellulolyticus. Canadian Journal of Microbiology 26, 760-765.

Shepherd, M. F., Tong, C. C. \& Cole, A. L. (1981). Substrate specificity and mode of action of cellulase from the thermophilic fungus Thermoascus aurantiacus. Biochemical Journal 193, 67-74.

Shinitzky, M., Katchalski, E., Grisaro, V. \& SHARON, N. (1966). Inhibition of lysozyme by imidazole and indole derivatives. Archives of Biochemistry and Biophysics 116, 332-343.

Shinmyo, A., Garcia-Martines, D. V. \& Demain, A. L. (1979). Studies on the extracellular cellulolytic enzyme complex produced by Clostridium thermocellum. Journal of Applied Biochemistry 1, 202-209.

Shoemaker, S. P. \& Brown, R. D., JR (1978). Characterization of endo-1,4- $\beta$-D-glucanases puri- fied from Trichoderma viride. Biochimica et biophysica acta 523, 147-161.

Stewart, B. J. \& Leatherwood, J. M. (1976). Depressed synthesis of cellulase by Cellulomonas. Journal of Bacteriology 128, 609-615.

Tong, C. C., Cole, A. L. \& Shepherd, M. F. (1980). Purification and properties of the cellulases from the thermophilic fungus Thermoascus aurantiacus. Biochemical Journal 191, 83-94.

Yamane, K., Suzuki, H. \& Nisizawa, K. (1970). Purification and properties of extracellular and cellbound cellulase components of Pseudomonas fluorescens var. cellulosa. Journal of Biochemistry 67, 19-35.

ZemeK, J., Augustin, J., BorRiss, R., Kuniak, L., Svabova, M. \& Pacova, Z. (1981). Polysaccharidehydrolyzing enzymes in the genus Bacillus. Folia microbiologica 26, 403-407. 